\title{
Interdependence Day and Magna Charta: James Hamilton's Public Diplomacy in the Anglo-World, 1907-1940s ${ }^{1}$
}

\author{
Donald M. MacRaild, University of Ulster \\ Sylvia Ellis, Northumbria University \\ Stephen Bowman, Northumbria University
}

[Authors Original Manuscript, pre-publication version, 2013; published 2014]

\begin{abstract}
This article discusses the use of the Magna Charta as a universal symbol of democracy in the AngloWorld in the early $20^{\text {th }}$ century. It focusses on the role played by one group, the International Magna Charta Day Association (IMCDA), in a global movement to unite and educate the Englishspeaking peoples through the promotion of the great charter. In searching for a world-wide AngloSaxon patriotism, this society promoted strong connections and the laudation of what it called 'Interdependence Day'. The article concludes that although the IMCDA may have been only one element in the widening and strengthening of Anglo-world connections, it was an important one that has been previously neglected.
\end{abstract}

Keywords: Magna Charta; Magna Charta Day; English-speaking peoples: Anglo-Saxonism; AngloAmerican Relations; Anglo world; J.W. Hamilton, public diplomacy

The Magna Charta stands for the first agreement of a European monarch to abide by a signed and sealed abridgement of his prerogatives. From this notable beginning we have advanced to popular democracy, and are not so very far off the achievement of universal suffrage, for men and women alike.

Boston Globe, 15 June 1893

One of the strongest bonds between England and the United States is the fact that their civil and religious liberties are derived from the same source [i.e. Magna Charta]. It is a characteristic of American enthusiasm that an event in English history of 700 years ago should stimulate keener interest in the States than in England itself.

Register (Adelaide), 22 June 1922

\section{Introduction}

${ }^{1}$ The authors wish to thank the anonymous readers who improved an earlier version of this article. Don MacRaild also wishes gratefully to acknowledge the generosity of the AHRC (project grant $\mathrm{AH} / \mathrm{I} 001042 / 1)$, which facilitated his research. 
At the heart of notions of British identity are a series of values, customs and beliefs that are English in origins. The concept of a 'Norman Yoke', so vividly described by Christopher Hill, exemplified a broad-based struggle to restore Anglo-Saxon political liberties and individual rights to the governance of England. ${ }^{2}$ Although the Norman Yoke itself has passed from popular or intellectual usage, the centrepiece of medieval attempts to curtail Norman monarchical power, the Magna Charta, retains the same ideas because it is a founding text of the liberties that the thirteenth-century barons had sought to reassert at Runnymede. For centuries, these myths of liberty continued to exert a powerful authority in English and British ideology. Magna Charta influenced theorists of the seventeenth century who utilised these same values to support the parliamentary case during the English Civil War. More important was the globalisation of these values. 'Albion's seed'3 was a body of values as well as of genes. Settlers and their offspring carried ideas of liberty throughout the Anglo-world - by which we specifically mean the British colonies of settlement: the United States, Canada, South Africa, Australia, New Zealand and Newfoundland. Indeed, the great charter became popularized as 'the principal bulwark of English liberty'. 4 For Nicholas Murray Butler, President of Columbia University, speaking on the $700^{\text {th }}$ anniversary of Runnymede signing, 'the Great Charter really did lay the foundation of [both] modern English and American liberty. ${ }^{, 5}$ Indeed, since America was sprung from British loins most colonial charters and state constitutions, and the 1787 federal Constitution and its amendments, contained clauses that rested on the general principles of the Magna Charta of limited government under the rule of law. And yet the American Revolution represented a Runnymede-style rebuttal of arbitrary governance (this time of colonists over the mother country). Thus, in 1800, the idea of a shared British and American adherence to the principles of Magna Charta would have seemed unlikely. For, in the period of the early Republic,

\footnotetext{
${ }^{2}$ Christopher Hill, 'The Norman Yoke', in idem, Puritanism and Revolution: Studies in the Interpretation of the English Revolution of the $17^{\text {th }}$ Century (1958; London: Pimlico, 1991 edn), 46-111.

${ }^{3}$ David Hackett Fischer, Albion's Seed: Four British Folkways in America (New York: Oxford University Press, 1992).

${ }^{4}$ Henry Hallam, View of the State of Europe during the Middle Ages (Boston: William Veazie, 1864 edn), 3 vols, II, 310.

5. Nicholas Murray Butler, Magna Charta, 1215-1915. An Address Delivered before the Constitutional Convention of the State of New York, in the Assembly Chamber, Albany, June 15, 1915 (New York, 1915), p.15.
} 
Britons were not the kin to whom Americans would look for legitimacy for their political system. Quite the opposite was in fact the case. Patriotic societies sprang up in America in the 1820s which extoled the revolution and the War of 1812 as markers of disjuncture with Britain, and relations between the two countries remained frosty for most of the century due to mutual suspicion and ongoing border and trade disputes.

This caesura was not, however, permanent. There was a remarkable return transformation in the late nineteenth century when in the aftermath of the Venezuela crisis (1895) Anglo-American relations witnessed a 'great rapprochement' characterised by cooperation during the SpanishAmerican War of 1898 and the Anglo-Boer War - an understanding based firmly on Anglo-Saxon sentiment. ${ }^{6}$ By the time of Queen Victoria's Diamond Jubilee in 1897, an event that undoubtedly increased the goodwill between the US and Great Britain, the New York Times lauded the achievements of the English-speaking people and even declared: 'We are a part, and a great part, of the Greater Britain which seems so plainly destined to dominate this planet. ${ }^{7}$ By 1910, American patriots were beginning to link their identity more firmly to England's through a shared cultural heritage. Moreover, proponents of Anglo-American amity, such as Nicholas Murray Butler extended intellectual principles into practical work-Murray in his capacity, from 1925, as president of the Carnegie Endowment for International Peace, an organization which "espoused the principle that mutual understanding between people from different cultures and nations could advance the cause of international peace." 8

Broader geopolitical developments encouraged such thinking. Recognizing that its world supremacy was now under threat from the United States and Germany (with their strong economies, growing navies, and expanding empires), Britain preferred to face the more immediate danger from a

\footnotetext{
${ }^{6}$ Bradford Perkins, The Great Rapprochement: England and the United States, 1895-1914 (New York: Atheneum, 1968); Stuart Anderson, Race and Rapprochement: Anglo-Saxonism and Anglo-American Relations, 1895-1904 (Rutherford, NJ: Fairleigh Dickinson University Press, 1981).

${ }^{7}$ New York Times, 24 June 1897.

${ }^{8}$ Justin Hart, Empire of Ideas: The Origins of Public Diplomacy and the Transformation of U.S. Foreign Policy (Oxford: Oxford University Press, 2012), p. 22
} 
militaristic Germany in relative harmony with its former colony. As Britain moved away from its 'splendid isolation', and as the United States became less critical of the British Empire as the US acquired its own territories and protectorates in Latin America, the Caribbean, and the Far East, the two nations gravitated towards one another. In a cultural and intellectual milieu that lauded the Anglo-Saxon race, with closer transatlantic elite connections fostered by the Anglo-American 'marriage market' and faster travel, and with an acknowledgement that common values and a common language united them, attempts to encourage even closer relations multiplied. ${ }^{9}$

By the twentieth century, with Britain and America closer than at any time since one was a colony of the other, neo-Britons perpetuated the idea of Magna Charta and the American Constitution as models of governance: the one sprung from the other, both of them uniting the Anglo-Saxon peoples. The extent to which Magna Charta acted as a synonym for world-wide AngloSaxon unity is remarkable. For it encapsulated meanings and values far beyond the specific historical moment of the historic signing at Runnymede. Instead of some long-forgotten medieval agreement, Magna Charta became a monument of enduring relevance, reflecting a state of mind which united the English-speaking world, but which also spoke to diverse other communities. Catholic lawyers in the US were, for example, told that the Anglo-Norman settlement enshrined at Runnymede was the source of their 'true liberty'. ${ }^{10}$ The New York Times described new pro-ethnic legislation as a 'red man's Magna Charta'. ${ }^{11}$ Labour organisations around the world evoked the sacred texts in demands for wages, arbitration, shorter working weeks, and other concessions. ${ }^{12}$ And in 1939 the Order of the First Virginians gave us a new usage of the medieval charter when they gathered to mark the

\footnotetext{
${ }^{9}$ Josiah Strong, Our Country: Its Possible Future and its Present Crisis (New York: American Home Missionary Society, 1885); John R. Dos Passos, The Anglo-Saxon Century and the Unification of the English-Speaking People (New York: G.P. Putnam,1903).

${ }^{10}$ New York Times, 15 July 1957.

${ }^{11}$ New York Times, 10, 29 June 1923, for the discussion of first-nation rights.

${ }^{12}$ For instance, the NZ Trades and Labour Council described the country's Conciliation and Arbitration Act as 'the magna charta of labour', Thames Star, 31 July 1902. And, in 1936, President Franklin D. Roosevelt referred to the Social Security Act of 1935 as 'a new Magna Charta for those who work', Address at Brooklyn, New York, 30 October 1936.
} 
establishment of the first legislative assembly in the colonies in 1619. For them, this was the moment of the 'American Magna Charta'. ${ }^{13}$

It was with these ideas of the essentialist character of the ancient text that the International Magna Charta Day Association (IMCDA) was founded during the Edwardian era. This article explores how, and why, this transformation came to pass and how one organisation, the IMCDAsometimes called just the Magna Charta Association—-became the focal point of a global movement to utilise the great charter to unite and educate the English-speaking peoples. In searching for a world-wide Anglo-Saxon patriotism, this society promoted strong international connections and the laudation of what it called 'Interdependence Day'. ${ }^{14}$ It was, in many ways, a non-state actor engaging in what would now be termed as cultural diplomacy; one of the earliest Anglo-American networks that linked the official government hope for closer ties between the Anglo-Saxon nations to the peoples that occupied those lands. Although not deliberately playing this role, IMCDA's architect and key activist, J.W. Hamilton was, in effect, a civilian advocate of both British and American foreign policy objectives. This is, therefore, a study of one modest actor and his world, rather than the milieu of men and women he sought to influence. In this respect, we demonstrate a level of public diplomacy complementary to, but below, that described in Hart's important new study. $^{15}$

\section{The Formation, Organisation and Objectives of the IMCDA}

The IMCDA was founded in Minnesota in 1907 by James Woodburn Hamilton. Born in Ontario, Canada, in 1866, his Presbyterian father, John, was a Scottish-born collector of customs, and his

\footnotetext{
${ }^{13}$ Washington Post, 30 April 1939.

${ }^{14}$ Coined by Oil City Derrick (Pennsylvania), 29 August 1928.

${ }^{15}$ Hart, Empire of Ideas.
} 
mother, Cecilia, was English. ${ }^{16}$ From comfortable lower-middle-class circumstances-what we would today term as 'white collar'-Hamilton acquired a good education (something quite marked in his voluminous correspondence) and a decent job. In 1920, he was working as a sales manager in St Paul, Minnesota, and living at 147 Kent St, as a boarder. ${ }^{17}$ However, his work was merely a means by which to progress his campaigns: for a common, global English language; for Magna Charta Day; for a peace stamp to be embraced by all the world's post offices; for pacifist education; and for peace and international understanding more generally. At the age of 51, in April 1917, he became a US citizen. $^{18}$

The timing of the foundation of the IMCDA in the United States, and the background of its founder, suggest an initial Progressive Era impulse that was acted upon within a context of growing Anglo-Saxon bonds and a strengthening Anglo-American relationship. From its inception, the IMCDA's true purpose was the promotion of peace; an aim shared by a growing number of reformers and activists of the period, from the American School Peace League that hoped for peace education in schools to the Carnegie Endowment for International Peace, created in the belief that world peace could be achieved through stronger international law and governance. The IMCDA's intention, stated by Hamilton, was redolent of its time:

To develop English-speaking patriotism by linking the English-speaking nations still more closely together thus aiding world peace; and arousing our race consciousness to make it more difficult for unwise racialism to develop and for our enemies to sow trouble among us. The movement is non-sectarian and non-racial. ${ }^{19}$

These words capture a sense of the nascent Anglo-American friendship (indeed the early twentieth century saw the formation of a number of transatlantic elite networks with similar aims, including the

\footnotetext{
${ }^{16}$ Census of Canada, 1871, Ontario District 30, Sub-District C, Division 3.

${ }^{17}$ Fourteenth Census of the US: 1920-Population, City of St Paul, 159/89/9B.

${ }^{18}$ Lawrence Leonard to Calvin Coolidge, 12 January 1925, Papers of Calvin Coolidge, Reel 145, Series 1, Case File 1848, LOC.

${ }^{19}$ New York Times, 21 March 1926.
} 
Anglo-American League, the Pilgrims Society, and the English-Speaking Union (ESU) but also show the IMCDA was part of the battle between Anglo-Saxonism and Americanism that featured in late-nineteenth and early-twentieth-century angst over national identity. ${ }^{20}$ Social Darwinists and pseudo-intellectuals explained the global dominance of the English-speaking people in terms of raceexceptionalism and the 'white man's burden' and soon used these concepts as justification for the growing American empire. Anglo-Saxon populism reached its height at the turn of the century but was soon challenged by anti-imperialists and those who disputed the idea that 'true Americanism' rested on assimilation into an Anglophile culture, instead arguing for the accommodation of immigrant cultures in a multicultural America. Such debates, and a renewed nativism, reached a peak in the 1910s, when overseas immigration rose to historic heights. Anglo-Protestant Americans, as the dominant ethnic group, had hardly noticed the arrival of British and Canadian immigrants, but many of the newcomers hailed from eastern and southern Europe. Indeed between 1900 and 1909, two-thirds came from Italy, Austria-Hungary, and Russia. Many native-born Americans, and 'old' immigrants from northern and western Europe, and Canada, feared the 'new' immigrants who swelled the cities with their alien languages, customs, and Jewish and Catholic faiths.

The following decade also saw the number of immigrants from Mexico and Asia increase markedly. White Anglo Saxon Protestants asked if these immigrants could ever be '100 per American'. Hamilton's home state of Minnesota was one that saw a dramatic change in its population in the late nineteenth and early twentieth century, with over forty percent of its population foreign-born and by 1896 instructions for its elections were issued in English, German, Norwegian, Swedish, Finnish, French Czech, Italian, and Polish. Fears about the rapidity of this influx, and its impact on cities that were already struggling to cope with mass internal migration and industrialization, meant that in 1905 President Theodore Roosevelt had established a presidential commission to study immigrant-related problems (leading to a more unified Immigration and

\footnotetext{
${ }^{20}$ For a fuller discussion see Paul A. Kramer, 'Empires, Exceptions, and Anglo-Saxons: Race and Rule between the British and United States Empire, 1880-1910,' Journal of American History 88, no. 4 (March 2002): 1315-1353.
} 
Naturalization Bureau). Early in 1907 the Dillingham Commission was established to study the consequences of mass immigration. ${ }^{21}$ Nativists were soon lobbying the commission's members about the need for Americanization programmes and immigration quotas.

While more extremist groups, including the American Legion and the Immigration Restriction League, made alarmist claims about the dangers posed by newcomers who were subversive, criminal, and deficient in their intellectual and physical capacities, the Magna Charta Association preferred instead to promote the values of the charter as part of its 'Americanization work' and the 'development of good citizenship and law observance. ${ }^{22}$ By appealing not on the ground of Anglo-Saxon blood connections, but instead on the grounds of ancient English constitutional history, the IMCDA was part of shift toward greater emphasis on the importance of the adopted values of the English-speaking peoples rather than inherent strengths. After all, by 1914, Britain and the United States were able to commemorate the Treaty of Ghent as a celebration of 100 years of peace between the two nations (even if they had come perilously close to war on several occasions in between). It was hoped that universal ideals could be transmitted across the globe and that an education in democracy, freedom, individual liberty, and after World War I and the formation of the League of Nations, arbitration and conciliation, would help end conflicts and wars. Indeed, a recent study has shown that the term 'English-speaking people' grew in usage in the newspapers in London and New York from the 1890s and reached a peak in the 1920s as the term 'Anglo-Saxon' declined in popularity. ${ }^{23}$

Given this context, it is not surprising that the interwar period witnessed IMCDA support growing rapidly across the Anglo-world. There were two other reasons, however, for the Association's passionate advocacy of Magna Charta Day during this period. If 1907 had engendered

\footnotetext{
${ }^{21}$ Keith A. Fitzgerald, The Face of the Nation: Immigration, the State, and the National Identity (Stanford: Stanford University Press, 1996), 127.

${ }^{22}$ Letter from J.W. Hamilton to Charles Evans Hughes, 27 September 1924, Papers of Calvin Coolidge, Reel 145, Series 1, Library of Congress (hereafter LOC).

${ }^{23}$ Peter Clarke, 'The English-Speaking Peoples before Churchill,' Britain and the World 4, no. 2 (2011), 203; also idem, Mr Churchill's Profession: Statesman, Orator, Writer (London: Bloomsbury, 2012).
} 
hope of ensuring peace (or, if not, then a strong union against common enemies), the inter-war context was one of learning lessons from the hideous conflagration that had erupted in 1914. Amity between Anglo-Saxon countries had been demonstrated vividly in the trenches of France and on the beaches of Gallipoli. Magna Charta Day, and the IMCDA itself, were part of a singular effort to keep the Anglo-world as one and so to ensure peace, and if not peace then safety—safety from further war and resistance to the paths followed by Russia. As article (b) of the IMCDA's objectives put it, the association was intended to ensure 'holding more closely together and ... permitting no enemy to sow seeds of trouble between us. ${ }^{24}$ The message of humanity, allied to collective interest, was clear. The co-operation of Anglo-Saxon peoples had helped defeat the Central powers; after 1918, they hoped to triumph in peace. Hence the IMCDA's pacific intent did not ring hollow. The Brisbane Courier recorded Abraham Lincoln's immortal words, 'America and Great Britain in peace and friendship perpetual', while noting that 'Magna Charta is indeed a link between all the Englishspeaking peoples in the world ... [the] real peace-makers who are looking around these days for points of contact rather than divergence. ${ }^{25}$ Even more starkly, Rev. William Johnson, president of the IMCDA, declared that 'Anglo-American unity is the greatest peace factor in the world today', likening the efforts of his organisation to those of the League of Nations and the English-Speaking Union. $^{26}$ The shared experience of war, of course, underscored the eager efforts of fraternity and understanding, and the IMCDA was recognised for promoting such feelings in literature as well as events. ${ }^{27}$ Such values held up in the 1930s, too (even if the British government's hopes for a permanent transatlantic partnership were rebuffed by the US's non-interventionist policies). ${ }^{28}$ As the Boston Daily Globe claimed, in June 1930, 'world peace and respect for law are today two dominant issues, and any movement which has for its purpose the promotion of these ideals commands the

\footnotetext{
${ }^{24}$ Reported in the New Age Magazine, 31, 1 January 1923, 374.

${ }^{25}$ Brisbane Courier, 13 June, 3 September 1923. The sentiments repeated in the same organ, 6 June 1925.

${ }^{26}$ Register (Adelaide), 21 January 1926.

${ }^{27}$ The English-Speaking World, 5 (1923), 284.

${ }^{28}$ George W. Egerton, 'Britain and the "Great Betrayal": Anglo-American Relations and the Struggle for United States Ratification of the Treaty of Versailles, 1919-1920,' Historical Journal 21, no. 4 (1978): 885-911.
} 
attention and cooperation of farsighted citizens. ${ }^{29}$ In Australia, they reckoned that, in the early 1930s, 200 million people lived under laws sprung from Magna Charta; as such, the Minister of Education instructed teachers in state schools to make 'suitable references' to the fact. ${ }^{30}$

IMCDA's popularity was also due to improved leadership and organization throughout the Anglo-world. By this period the Association had established itself in the US, Great Britain, Canada, Australia New Zealand, Newfoundland, South Africa, the British West Indies, Southern Rhodesia, and Egypt-Sudan. ${ }^{31}$ It was run by a President, Vice-President and Secretary (with Hamilton serving in the latter role throughout the period under study) alongside a Board of Directors that by the late 1930s included university presidents, editors/journalists, and supreme court justices. The organization ran on very limited funds (15 guineas in 1942) as it did not have a paid membership, instead relying on small donations from supporters. Hamilton did most of the outreach and networking himself. ${ }^{32}$ In the 1930s he travelled to England for several months at a time in his attempts to cultivate his British Empire connections, not least through a friendship with Leopold Amery MP, an India-born pro-imperial politician who served in a variety of ministerial roles in relation to the British colonies from the 1920 s to the 1940 s. ${ }^{33}$ It is clear, however, that in each of the Anglo-world nations, the Association had active and dedicated branches with sufficient followers to spread the word and attract the attention of influential elites to further its aims.

\section{The Networks and Activities of the IMCDA}

\footnotetext{
${ }^{29}$ Boston Daily Globe, 13 June 1930.

${ }^{30}$ Register (Adelaide), 15 June 1931.

${ }^{31}$ New York Times, 7 December 1921.

${ }^{32}$ Letter from J.W. Hamilton to Leopold Amery, 17 April 1942.

${ }^{33}$ Deborah Lavin, 'Amery, Leopold Charles Maurice Stennett (1873-1955)', Oxford Dictionary of National Biography, Oxford University Press, 2004; online edn, May 2012 [http://www.oxforddnb.com/view/article/30401, accessed 13 June 2013].
} 
As its name suggests, the IMCDA intended to foster a permanent Anglo-world friendship by establishing international recognition of the anniversary of the signing of the medieval document at Runnymede on $15^{\text {th }}$ June each year. Magna Charta Day captured a vision of an anniversary to celebrate the connections between the medieval text and later liberties, most notably the American Constitution. ${ }^{34}$ In 1921, Rev. Johnson claimed to be favouring not an additional public holiday but recognition of the charter 'through magazine articles, newspaper editorials and sermons from pulpits'; for '[w]e wish only to educate the English-speaking nations to the origins of all modern civil and religious liberties ... our movement is purely educational' ${ }^{35}$ The press answered this clarion call with numerous attempts to provide potted histories of how Magna Charta underpinned the modern liberties of these seven nations. ${ }^{36}$

In essence, the ICMDA's efforts stood alongside official state attempts to foster enduring Anglo-American and Anglo-world links. Thus the IMCDA struck a chord which was marked by strong approval from heads of state and other senior politicians, a factor which helped glean further support from British and American politicians and other business, church and legal elites. A number of the IMCDA's supporters were prominent individuals with links to the other British-American groups. For example, people like Nicholas Murray Butler, James Bryce, along with Gilbert Parker, David Lloyd George and Arthur Balfour, were described by J.W. Hamilton in The New York Times in 1926 as having given the IMCDA their 'hearty endorsement'. ${ }^{37}$ Bryce, who died in 1922 , was the former British ambassador in America and had long been associated with the cause of improving British-American relations. In 1898 he helped found the Anglo-American League, of which Irish idealist and agricultural reformer Horace Plunkett, an honorary president of the IMCDA, had also

\footnotetext{
${ }^{34}$ Additionally, moments of Anglo-American unity were occasionally marked on the historic 15 June, for example when the two Ruskin Halls were found in St Louis and at Oxford. New York Times, 23 June 1900.

${ }^{35}$ Wisconsin Rapids Daily Tribune, 6 October 1921.

${ }^{36}$ Atlanta Constitution, 13 June 1926, provides a fine example, with a short history of western liberties beginning with the sacred charter.

37 New York Times, 21 March 1926.
} 
been a member. ${ }^{38}$ Bryce was also the president of the Pilgrims Society from 1915, and chaired the formal dinner that marked the Atlantic Union's amalgamation with the ESU in $1919 .{ }^{39}$ Similarly, the former British foreign secretary and prime minister, Arthur Balfour, was president of the British ESU. ${ }^{40}$ Meanwhile Gilbert Parker, a writer and MP — who had built up a mailing system to thousands of American contacts to distribute British propaganda in the US during the First World—was also a member of the Pilgrims and the British-American Peace Centenary Committee, and its successor in Britain, the Anglo-American Society. ${ }^{41}$

Hamilton pressured for a variety of forms of White House sponsorship, from support for the erection of Magna Charta bronzes in the legislative halls of the Anglo-world to asking the President to read an oration on Armistice Day that supported the fundamental laws enshrined in the charter. ${ }^{42}$ Recognizing the difficulties posed in asking that Magna Charta Day be made a US national holiday (not least because the nation already celebrated Thanksgiving, Labor Day, George Washington's birthday, and $4^{\text {th }}$ July), Hamilton pressed successive presidents to issue a proclamation in support of $15^{\text {th }}$ June. In November 1921, the IMCDA founder wrote to clarify that he wished Magna Charta Day to be recognized 'as a holiday of the spirit, an annual commemoration by the English Speaking Races' and not a legal holiday. ${ }^{43}$ Remaining dogged on the issue, he wrote again the following May, stating that Prime Minister Lloyd George 'very cordially supports this plan'. ${ }^{44}$ Although failing to secure a presidential proclamation supporting the day, the IMCDA found President Warren Harding responsive to its ideas. A Republican who remained suspicious of 'hyphenated Americans' who

\footnotetext{
${ }^{38}$ The Times, 28 July 1898 and 14 July 1898; New York Times, 21 March 1926.

39 The Times 13 February 1919; Anne P. Baker, The Pilgrims of Great Britain: A Centennial History (London: Profile Books, 2002), 178.

${ }^{40}$ The Times, 30 March 1930.

${ }^{41}$ M.L. Sanders, 'Wellington House and British Propaganda during the First World War', Historical Journal, Vol. 18, Issue 1 (1975), 130; 'British-American Peace Centenary: British Supporters of the Celebration', October 1912, Sulgrave Mss, SMTA, Box 1; ' $2^{\text {nd }}$ Meeting of the Committee', 2 August 1918, Sulgrave Mss, SMTA, Anglo-American Society Minute Book (1918-1924).

42 J.W. Hamilton to Woodrow Wilson, 27 February 1922, Papers of Woodrow Wilson, Reel 119, Series 2, LOC; J.W. Hamilton to Warren G. Harding, 8 July 1932, Reel 220, File 1656, Folder 1.

${ }^{43}$ J.W. Hamilton to George B. Christian, Jr., 28 November 1921, Papers of Woodrow Wilson

44 J.W. Hamilton to Warren G. Harding, 25 May 1922, Papers of Warren G. Harding, Reel 220, File 1656, Folder 1.
} 
tended to vote Democrat and opposed to Wilsonian internationalism, Harding declared in January 1921 that '[d]estiny has made it a historical fact that the English-speaking peoples have been the instrument through which civilization has been flung to the far corners of the globe'. ${ }^{45}$ He agreed to become the Honorary President of the IMCDA in 1921 and in response to the request wrote: 'Believing that you are doing a useful and patriotic work in your efforts to secure a commemoration of this occasion and a popular understanding of its significant to the Anglo-Saxon nations, I accept the position with pleasure. ${ }^{46}$ Acquiescence accorded enormous approval for the organisation. ${ }^{47}$ The Prime Minister of Australia, in 1921, also served in this capacity, as did J.G. Coates, the premier of New Zealand. ${ }^{48}$

By the mid-1920s many others had followed suit, with Harding's successor in the White House Calvin Coolidge, Northern Ireland premier James Craig, and the former Canadian premier, Robert Laird Borden, all counted among honorary presidents or strong supporters. ${ }^{49}$ Having gained this crucial endorsement, Hamilton and his fellow enthusiasts stepped up the pressure on Coolidge for a presidential proclamation in support of the Magna Charta day. In June 1924 they asked that it be included 'in the many birthdays which we, as a nation, observe' as the signing of the Magna Charta 'was truly the birthday of civil and religious liberty' and noted that 'the new citizen especially, would be benefited by knowing something of the day and its purposes.' Again the IMCDA was unable to gain presidential support for a special observance of the day, possibly because Coolidge was part of a Committee organized by the Sons of the American Revolution that was pushing for a federal Constitution Day (celebrated in Iowa from 1911) and also because there were

\footnotetext{
${ }^{45}$ Clarke, 'English Speaking Peoples', 231.

${ }^{46}$ New York Times, 7 December 1921.

${ }^{47}$ The president received a framed copy of the Magna Charta to mark his acceptance. Free Press (Carbondale, Ill), 23 August 1922.

${ }^{48}$ Evening Post, 14 June 1928.

${ }^{49}$ New York Times, 21 March 1926. For Borden, see Lethbridge Herald, 13 November 1934.
} 
similar pressures to celebrate Columbus Day (a federal holiday from 1937 onwards). ${ }^{50}$ This setback did not prevent the IMCDA from pursuing its efforts through other means.

In England and the United States alike, the IMCDA became a forum for fine dinners and considered lectures. Some of its members, especially in Washington, operated in American high society and had the ear of politicians, diplomats and officials, with many an IMCDA dinner listed as a 'capital society event'. ${ }^{51}$ And alongside the rhetoric of Anglo-Saxon peace evident elsewhere in the Magna Charta movement, there was occasionally a military element to proceedings in Washington. For Magna Charta day 1924 'all branches of the government and army and navy' were to be represented at a banquet, along with attendees from the 'embassies and legations'. The ESU was also included on the guest list, as were members of the 'hereditary societies. ${ }^{52}$ Similarly, Mrs Merchant Mahoney, the wife of the Commercial Secretary of the Canadian Legation, and later Canada's High Commissioner in Ireland, attended an IMCDA meeting in $1924 .{ }^{53}$ The Washington branch of the IMCDA also benefited from its proximity to the US political classes, with Senators Samuel Morgan Shortridge of California and James Thomas Heflin of Alabama both delivering speeches to the society at the $709^{\text {th }}$ anniversary celebrations. ${ }^{54}$

Magna Charta day also entered the calendar of the St George's Society (a charitable society of Englishmen and those descended from the English) and was specifically sponsored in the 1920s, by the Magna Charta Association. ${ }^{55}$ The Association certainly convinced newspapers in as diverse places as Adelaide and Iowa that this was a worthy venture based on shared liberties enshrined at

\footnotetext{
${ }^{50}$ Mary Jane Sevey to Calvin Coolidge, 7 June 1924 and Edward J. Clark to Mary Jane Sevey, 11 June 1924, Papers of Calvin Coolidge, Reel 145, Series 1, LOC.

${ }^{51}$ Washington Post, 8 June 1926; 17 June 1928.

${ }^{52}$ The $709^{\text {th }}$ anniversary of Magna Charta, for example, was celebrated by speeches on the army and navy delivered by officials from the military. Washington Post, 14 June 1924.

${ }^{53}$ Washington Post, 17 June 1928; Ottawa Citizen, 7 May 1946.

${ }^{54}$ Washington Post, 16 June 1924; Biographical Directory of the United States Congress, 'Heflin, James Thomas (18691951)' and 'Shortridge, Samuel Morgan (1861-1952)', bioguide.congress.gov, [Accessed 2 Jul. 2012].

${ }^{55}$ BC, 15 June 1922; Mercury, 18 June 1928; Argus, 4 April 1930. See also, Tanja Bueltmann and Donald M. MacRaild, 'Globalising St George: English associations in the Anglo-world to the 1930s', in Journal of Global History, 7, 1 (2012),.79-105.
} 
Runnymede. ${ }^{56}$ At Brisbane, in 1925, the St George's Society was lectured on 'the Magna Charta Association and the English-Speaking Union', the latter term becoming regularly used to capture its intentions. ${ }^{57}$ In the chair was Sir James Barrett, the prominent British doctor and former chairman of the British Medical Association, who became a civic leader in Melbourne, and who ran Australia's Magna Charta Association for years. ${ }^{58}$

\section{IMCDA in the United States}

Whilst Magna Charta day was a feature across the British world, the US-where the IMCDA had been founded — was the place these messages resonated most. Regardless of Mayor Bill Thompson's demagoguery in Chicago_which was largely met by incredulity elsewhere ${ }^{59}$ - by 1918 old American definitions of patriotism as anti-British had been re-defined. Magna Charta became a virtual bridge between the democratic traditions of the English and the Americans - a bridge which, thanks to the likes of the IMCDA, spanned the British World rather than just the Anglo-Atlantic. This is why patriotic societies, founded to memorialise the American victory over Britain, became patriotic in a way that was organically connected to England as the well-spring of American constitutional governance and liberties. Mr J.H. Belknap provided an interesting insight, in 1918, into how this sense emerged. During the war, he explained, when the unity of the English-speaking world had been of crucial importance, he hit onto an idea: 'On July 14 Inst, when we were celebrating Bastille Day ... I expressed to a group of friends that we might match that occasion by

\footnotetext{
${ }^{56}$ See for example the approving tone of articles in The Iowa Press Citizen, 13 October 1921, and the Register, 3 September 1923.

57 Brisbane Courier, 28 August 1925.

${ }^{58}$ Obituary, Argus, 7 April 1945.

${ }^{59}$ New York Times, 11 September 1928, 'Thompson Aide Says Mayor Never Hated King George'. Reporting from a meeting of the Commercial Telegraphers' Union, at which one of Thompson's advisors admitted that his Anglophobia was a campaign tool, the paper noted pithily that 'Chicago delegates exchanged glances of amazement'. See also, Douglas Bukowski, Big Bill Thompson, Chicago, and the Politics of Image, (Illinois: University of Illinois Press, 1998), 184-185.
} 
setting aside 15, June Magna Charta Day, in honour of Great Britain and the sowing of the seed of human liberty on her soil. ${ }^{60}$ Meanwhile Britain's Day, or British Day, was held across the $7^{\text {th }}$ and $8^{\text {th }}$ of December 1918, principally to commemorate the British war effort. The Pilgrims Society provided at least three of its members for the British Day organising committee and hosted a special dinner in New York, at which the society's president Chauncey Depew - a former Republican senator and president of the New York Central Railroad - told guests 'uninterrupted peace' between Britain and America was the 'fruitage in the centuries of Magna Charta, the Bill of Rights, and the American Declaration of Independence, in common principles and ideals' ${ }^{61}$

Like other paeans to British-American cooperation, although more gushing in the aftermath of victory over Germany, Britain's Day was as much about celebrating 'resolute Anglo-Saxon determination' as it was about the two countries becoming yet 'more firmly linked together to insure the peace of the world. ${ }^{62}$ Britain's Day did not escape the notice of the British Government, who were informed of a mass meeting of 5,000 people in New York which enthusiastically gave 'Three cheers for a democratic King, ${ }^{63}$ It was the success of the events of December 1918 that moved Hulbert to write that Magna Charta day should become a new annual 'Britain's Day', and one that the 'whole world might join with England in the celebration of an event significant to the Englishspeaking nations and almost as significant to constitutional government everywhere.' For Hulbert, victory in the First World War was a victory for 'all the fundamental things for which Magna Charta

\footnotetext{
${ }^{60}$ New York Times, 29 December 1918. Belknap was responding to an earlier letter by Henry Woodward Hulbert, who thought that the recently celebrated 'Britain's Day' provided a good basis for a more permanent celebration on 15 th June. New York Times, 21 December 1918.

${ }^{61}$ New-York Tribune, 9 November 1918 and 7 December 1918. Charles W. Eliot and John A. Stewart were Pilgrims members and on the national committee to organise British Day. Stewart was heavily involved with the Sulgrave Institute. See 'Proceedings at a Complementary Luncheon', 14 April 1919, Sulgrave Mss, SMTA, Box 2; Perkins, The Great Rapprochement, 297; New-York Tribune, 28 January 1918; Alton B. Parker, one-time Democratic candidate for the US presidency, also helped organise British Day and was associated with the Pilgrims and with the Sulgrave Institute. See New-York Tribune, 9 November 1918; Proceedings from a dinner for James Bryce, 13 December 1912, Sulgrave Mss, SMTA, Box 1; 'Dinner in Honour of Henry White', 11 January 1910, Brittain papers, BLPES, Box 5; Kousser, Shaping of Southern Politics, 195; New York Times, 8 December 1918.

${ }^{62}$ New-York Tribune, 8 December 1918. These extracts are from a letter sent by the US General Pershing.

63 'Western and General Report No. 98', 11 Dec. 1918, The National Archives [TNA], Cabinet Papers, CAB 24/150.
} 
stands'. ${ }^{64}$ This had been the same for Sir James Barrett, the IMCDA's leader in Australia, who felt that WWI had been about defending the principles wrested from the craven King John. ${ }^{65}$ Likewise, on a trip to Minneapolis - the founding home of the IMCDA- he declared that 'close cooperation between the United States and the British Empire was a "prime requisite for the peace of the entire world'. ${ }^{66}$

Sundry others in America had taken Magna Charta to heart. Advocates of a post-war Magna Charta Day included the United States Daughters of 1812, a patriotic society founded in 1892 . It is ironic that an English symbol such as this should be taken up by a society founded on the $77^{\text {th }}$ anniversary of General Andrew Jackson's defeat of a British invading force at New Orleans, in 1815, at what was the last battle of that war. However, their celebration of Magna Charta did not occur until after the 1890s rapprochement and another war - that of 1914-18 - brought the former enemies together. 'The National Society of the U.S.D. 1812 desires the state of Georgia to celebrate June 15 in an annual commemoration of Magna Charta day (not a legal holiday), the great foundation of our liberties.' In so doing, they would join 'seven English-speaking nations [who] will unite to observe this great event - the United States, Canada, Great Britain, Australia, South Africa, India, New Zealand.' The Daughters duly did this in 1921, the first occasion upon which 'the foundation of the liberty of the seven English-speaking peoples' was marked in the US. ${ }^{67}$ More than 2000 churches and Sunday schools adhered to the celebrations of that year. ${ }^{68}$ According to American reports, this figure had mushroomed to 20,000 by $1925 .{ }^{69}$ In the late $1920 \mathrm{~s}$, the association continued to

\footnotetext{
${ }^{64}$ New York Times, 21 December 1918.

${ }^{65}$ Mercury, 18 June 1928.

${ }^{66}$ Bluefield Daily Telegraph, 9 September 1936.

${ }^{67}$ Atlanta Constitution, 7, 14 June 1921.

${ }^{68}$ Sydney Morning Herald, 27 May 1922. I n this report, the seven English-speaking nations included Newfoundland at the expense of India.

${ }^{69}$ Atlanta Constitution, 13 June 1926.
} 
campaign for schools and churches to continue to mark what had become International Magna Charta Day, with thousands of leaflets being distributed. ${ }^{70}$

The Daughters of the Revolution, a classic example of the patriotic society formed in memory of victory over British tyrants, was another organisation which, in these days of warmer Anglo-American relations, now fostered visions of inheritance-inheritance of ancient English liberties which, both in their original and American forms, might ensure international good will and peace. Thus by the 1930s, at least one chapter, in Georgia, had taken up the name of Edmund Burke, rather than Tom Paine, for its branch and was welcoming political candidates to speak to them on 'strictly literary' topics under the aegis of the Magna Charta lecture. ${ }^{71}$ The subject also appeared on the historical programme of the Daughters of the Revolution in $1938 .^{72}$ The catalyst had been Hamilton's good work in writing to such organisations. However, the Daughters needed little persuading. As early as 1924 they proclaimed:

We have dreamed that some day Magna Charta day might become the greatest outstanding world day, on which the free minds in every country will join us in spirit and which in time will make the nations themselves realize that they must behave towards each other as we individually behave towards each other. ${ }^{73}$

In that year, the Daughters duly celebrated Magna Charta Day and Flag Day with addresses, lectures and song; and they marked the former again in September 1925. The Sons of the American Revolution were similarly approving, reporting the international day in their journal. In small towns like Gastonia, North Carolina, mayors, such as Emery B. Denny, urged citizens to observe Magna

\footnotetext{
${ }^{70}$ Mercury (Hobart), 31 May 1928.

${ }^{71}$ Atlanta Constitution, 16 March 1936. In this case, Wash Larsen, gubernatorial candidate.

${ }^{72}$ Atlanta Constitution, 19 June 1938.

73 Atlanta Constitution, 18 May 1924.
} 
Charta Day. ${ }^{74}$ In 1927 there appeared a marching song, Magna Charta, which was written for the association by John Philip Sousa. ${ }^{75}$ Meanwhile, American lawyers regularly heard lectures on Magna Charta because of its legal importance. ${ }^{76}$ Furthermore, the well-established Daughters and Sons of the Revolution and of 1812, were joined by other patriots, such as the Society of Cincinnati, founded in 1784, to honour American Revolutionary officers, and the Colonial Dames, women descended from pre-1750 stock. To these were added new groups who deliberately picked out the organic English connection: the Magna Charta Dames and the Baronial Order of Runnymede. ${ }^{77}$ It was even suggested that George Washington was descended from 'several of the Norman barons who wrested from King John the grant of the great charter of English liberties. ${ }^{78}$ Similarly, in 1935 , 150 women 'lineal descendants of the English barons who obtained Magna Charta', met at lunch at the Huntingdon Valley Country Club, Philadelphia. ${ }^{79}$ The love of liberty thus became almost a biological inheritance.

Washington DC's Mrs M. de Clare M. Berry demonstrates well the connections that existed between the 'lineal descendants' of the Runnymede barons and the more traditionally American patriotic and genealogical societies. Mrs Berry was a member of the Magna Charta Dames, but was also a member of the United Daughters of the Confederacy (UDC) and the Daughters of 1812, and was a 'regent' of the Daughters of the American Revolution. ${ }^{80}$ She also claimed descent from the early English settlers of Virginia and traced her lineage to both Edward I of England and Louis IX of France, and was a member of the International Order of Descendants of Crusaders. In addition, she was head of the District of Columbia branch of the IMCDA and was joined by Mrs Redwood

\footnotetext{
${ }^{74}$ Atlanta Constitution, 15 June 1924, 20 September 1925. See also their organ, which reported such activities by the Daughters: Daughters of the American Revolution Magazine, 61 (1927), 480; E.g. Minute Man, vol. 21 (1927), 82; Gastonia Daily Gazette, 16 June 1934.

${ }^{75}$ Zanesville Signal, 27 November 1927, advertised as part of a 'Sousa Concert Programme'.

${ }^{76}$ E.g. New York Times, 1 April 1928, lecture by William D. Guthrie of the New York Bar Association.

${ }^{77}$ Washington Post, 14 June 1934; 13 June 1935.

${ }^{78}$ Washington Post, 6 June 1932.

${ }^{79}$ New York Times, 19 June 1935; Washington Post, 28 February 1936

${ }^{80}$ Washington Post, 12 April 1924 and 6 February 1927. In these newspaper reports married women are invariably named using their husband's full name.
} 
Vandergrift, fellow 'patroness' of the UDC. ${ }^{81}$ Meanwhile Mrs Howard Hodgkin, another of Mrs Berry's IMCDA compatriots and wife of the one-time acting president of George Washington University, was a member of the Daughters of the Barons of Runnymede. ${ }^{82}$ Mrs Berry's AngloAmerican identity reconciled a distinctly aristocratic streak with membership of organisations whose pro-Americanism was originally defined against English, or British, tyranny and monarchism.

But elsewhere, as self-proclaimed 'settlers from the mother country', ${ }^{83}$ the Daughters of the American Revolution saw continuity and not change in the Declaration of Independence. For them, it was a 'protest against the violations by the kingly power of these fundamental rights of Englishmen'. ${ }^{84}$ One can well imagine Mrs Berry-proud Anglo-Saxon that she must have beenattending a UDC event in Baltimore in honour of Magna Charta dressed, as she was, in her 'quaint old English bridal costume with the white satin poke bonnet and veil. ${ }^{85}$ Such a dichotomous identity was possible because Magna Charta, as an emblem of English roots, had been taken out of both its historical context and national contexts. It had become an international symbol of Angloworld liberty.

\section{Opposition to the IMCDA}

There were, however, dissenting voices in the US. These were most vocal in the 1920 s, a decade pockmarked with intolerance, and characterised by the resurgence of the Ku Klux Klan, fears of communism at home and abroad, and strident debates about the nature of Americanism. During this period anxieties emerged about the potential subversion of traditional American holidays by the Magna Charta Day celebrations. In 1925, the editor-in-chief of Hail Columbia, a patriotic magazine

\footnotetext{
${ }^{81}$ Washington Post, 12 April 1924, 6 February 1927 and 17 June 1928.

${ }^{82}$ Washington Post, 16 June 1924 and 17 June 1928; Washington Times, 23 October 1921.

${ }^{83}$ Atlanta Constitution, 18 May 1924.

${ }^{84}$ Washington Post, 10 September 1933.

${ }^{85}$ Washington Post, 22 November 1933.
} 
from Hamilton's home city, wrote to the President to alert him to the 'harmful influence upon true Americanism' from the activities of the IMCDA, noting the overshadowing of the American Declaration of Independence and the Stars and Stripes (the association had plans to design a flag based on the principles of the Magna Charta) ${ }^{86}$ Irish-Catholic Americans, not often at ease with Anglo-American friendship, opposed the idea that Magna Charta was the founding text for Americans which some believed it do be. In 1921, as the Daughters of 1812 sat down to a celebratory dinner, Edward McSweeney of the Boston Knights of St Columba said his organisation opposed the move on the grounds that 'American liberty did not derive from Magna Charta. American liberties arose from a denial [by the British] of the primary human rights set forth imperfectly in Magna Charta. ${ }^{87}$ The Free City of Boston also opposed the mooted idea that 'Americans and Englishmen might unite in keeping two anniversaries. Memorial Day and Magna Charta Day. ${ }^{88}$ The Knights took their impetus from the American History Commission, a number of whose Irish-American members attended the Knights' event that made this assertion. The Commission had declared Magna Charta Day as one of the "new movements to discredit and eclipse American patriotic holidays. ${ }^{, 89}$ This prompted an angry response by a letter-writer, William Kerr, against 'the chairman of a self-appointed sectarian American historical commission'. For Kerr, Magna Charta, though imperfect, was 'the well-spring of our institutions, the first great codification of our racial principles. 90

The so-called 'McAndrew trial' in Chicago in 1927 was a particularly striking airing of these worries of Magna Carta Day’s subversive influence. William McAndrew, Chicago's superintendent of schools, was caught in the middle as local municipal politics clashed with national and international cultural trends. What was ostensibly a Chicagoan Board of Education tribunal

\footnotetext{
${ }^{86}$ Lawrence Leonard to Calvin Coolidge, 12 January 1925, Papers of Calvin Coolidge, Reel 145, Series 1, Case File 1848 , LOC.

${ }^{87}$ New York Times, 8 September 1921.

${ }^{88}$ New York Times, 16 June 1923.

${ }^{89}$ New York, 8 September 1921.

${ }^{90}$ New York, 11 September 1921.
} 
investigating charges of insubordination on the part of McAndrew soon turned into a high-profile campaign by the city's mayor to reveal a nation-wide 'conspiracy to distort American history in behalf of the king of England'. ${ }^{91}$ In truth, McAndrew's tribunal had always been something of a political football and had largely been engineered by William Hale Thompson, the city's Caponebacked, Republican mayor and presidential wannabe, to oust the unpopular school superintendent. ${ }^{92}$ The personal attack on McAndrew had started during the 1927 mayoral election, with Thompson promising, if he was elected, to sack this 'stool pigeon of King George', so that 'our school books will breathe patriotism again'. ${ }^{93}$ Whilst McAndrew was also accused of incompetence and a string of other inadequacies in relation to his overseeing of the Chicago school system, the over-arching theme of the criticisms levelled against him was in relation to his alleged pro-Britishness.

Thompson was something of a populist, and a large part of his Anglophobia was simply a vote-winning performance for the benefit of the city's Irish and German communities, and was also an effort to tap into isolationist sentiments nationally. ${ }^{94}$ Yet, the fallout of the McAndrew trial rumbled on for months, indeed years, and attracted international press coverage. Witnesses were called forth testifying to a conspiracy by groups like the IMCDA, the Pilgrims Society, the Sulgrave Institute, the Rhodes Scholarship Foundation, and the English-Speaking Union (ESU) to disseminate pro-British propaganda in American schools, bring about the annexation of America by the British Empire, and to replace the Fourth of July holiday with the $15^{\text {th }}$ June. ${ }^{95}$ This was not the first time the Pilgrims, the Sulgrave Institute, the Rhodes Scholarships, the ESU and the IMCDA had all been identified as part of a widespread and subversive effort to distribute pro-British propaganda. New

\footnotetext{
${ }^{91}$ Chicago Daily Tribune, 1 April 1927.

92 Benjamin D. Rhodes, 'Anglophobia in Chicago; Mayor William Hale Thompson's 1927 Campaign Against King George V', Illinois Quarterly, Vol. 39 (Summer, 1977): 5-14; Dominic A. Pacyga, Chicago: A Biography (Chicago: University of Chicago Press, 2009), 242-246.

93 Chicago Daily Tribune, 28 March 1927 and 1 April 1927.

${ }^{94}$ Bukowski, Big Bill Thompson 189.

95 The Times, 16 November 1927, 18 November 1927 and 23 March 1928; Chicago Daily Tribune, 3 November 1927 ; The IMCDA were described by one witness as the 'Magna Charta Association for annihilating the Fourth of July'. See The Times, 18 November 1927. McAndrew was allegedly a member of the ESU, see Chicago Daily Tribune, 20 October 1927.
} 
York's commissioner of accounts, David Hirshfield - anticipating the McAndrew case by a couple of years - had focused on the five associations in a 1923 report into anti-American history books, accusing the IMCDA in particular of trying to 'seduce America into the British Empire. ${ }^{96}$ That sceptical contemporaries lumped these groups together is significant in itself, suggesting they occupied a shared place in the public's imagination. Columbia University was also strongly implicated. A number of the university's history professors had allegedly published revised and proBritish accounts of key American historical events, whilst a meeting of historians convened by Nicholas Murray Butler in Philadelphia in 1917 had apparently 'presented a resolution calling for the revision of text-books to promote a pro-British state of mind' ${ }^{97}$ It is an interesting lesson in the selective reading of history that, at the meeting of the American Historical Association in Philadelphia in December 1917, after the US had entered the war as an 'associate power' rather than a full ally of the British, an academic - from Columbia University, no less-condemned the 'misguided sense of patriotism' that was seemingly encouraging some writers to revise histories of the American Revolution 'to do away with the anti-British sentiment' ${ }^{98}$

If some historians could be criticised for being excessively pro-American to the point of Anglophilia in 1917 — when British-American co-operation had an urgent, wartime motivation-the opponents of Columbia University's unpatriotic 'pro-Britishers' in 1927 may have been equally influenced by their own contemporary events. Throughout the 1920s, a number of contentious issues characterised official British-American diplomatic relations. The most important of these centred on naval disarmament and Britain's war debt to the US, whilst there was also some acrimony surrounding the 1919 Paris Peace Conference and membership of the League of Nations. This latter issue partly motivated Bill Thompson's campaign against British influences, just as one of the witnesses at the McAndrew trial—a former justice of the Supreme Court-believed that the there

\footnotetext{
${ }^{96}$ New York Times, 4 June 1923.

97 The Times, 16 November 1927; Chicago Daily Tribune, 15 October 1927.

${ }^{98}$ Evening Public Ledger, 29 December 1917.
} 
was a conspiracy to 'mould the minds of the children to the theory that Britain should maintain naval supremacy' and that everyone in the ESU wanted to write off the British war debt. ${ }^{99}$ Yet, the kind of aggressive Anglophobia articulated by the McAndrew witnesses seemed increasingly anachronistic by 1927, even if it was influenced by the rivalries that marked the formal British-American relationship in the 1920 s and much of the 1930 s. ${ }^{100}$ There was a further layer of meaning to the opposition to the IMCDA however, since, as one journalist in Australia pointed out, the Irish and German lobbies in the US had nearly succeeded in allying America to the Central powers - had they done so English-speaking unity would have been no more secure than it had been in the aftermath of the American Revolution or during the War of $1812 .{ }^{101}$ Since this counterfactual possibility did not come to pass, the dissentient voices of the KOC and the Commission may have raised the ire of some, but they ultimately had hardly more power than those Irish nationalists who, in 1897 , had opposed American celebrations of Victoria’s Diamond Jubilee by Americans. ${ }^{102}$

The irony of the sensational McAndrew show trial - at which the chairman had the American Declaration of Independence symbolically inserted into the minutes following what must have been one particularly harrowing session - is that the rather frenzied efforts to uncover a plot by BritishAmerican elites detracted from some underlying truths. ${ }^{103}$ If official British-American relations were cool, the work of the IMCDA would have had a renewed motivation. The IMCDA did seek to encourage schools to observe Magna Charta Day, just as the Sulgrave Institute had a 'Scheme of Education' in connection with the 1920 celebrations of the tercentenary of the landing of the Pilgrim Fathers. The Sulgrave scheme included plans to teach children about the various 'free institutions of the English speaking world', of which the Magna Charta was one, and outlined the need for a 'day of instruction' in 'Anglo-American common law', which they believed 'derived from a common source

\footnotetext{
${ }^{99}$ Chicago Daily Tribune, 17 October 1927 and 20 October 1927.

${ }^{100}$ Benjamin D. Rhodes, 'The Image of Britain in the United States, 1919-1929' in Brian J. McKercher (ed), AngloAmerican Relations in the 1920s: The Struggle for Supremacy (London: University of Alberta Press, 1991), $187-208$.

${ }^{101}$ Mercury (Hobart), 5 July 1926.

${ }^{102}$ Bueltmann and MacRaild, 'Globalising St George', 99-100.

${ }^{103}$ The Times, 16 November 1927.
} 
from the common-sense of common experience. ${ }^{104}$ Anglo-Saxon cultural unity clearly remained a feature of the rhetoric of groups like the IMCDA, the Sulgrave committees and the Pilgrims Society. These organisations represented a coalition of British-American elites, many of whom were also closely linked with the ESU. ${ }^{105}$

Similarly, Nicholas Murray Butler, in addition to delivering the $700^{\text {th }}$ Runnymede anniversary lecture for the New York Constitutional Convention, was president of the New York branch of the Pilgrims society from 1928, and also served on an education committee set up in 1912 to organise the school study of the one hundred years of peace between the 'English-speaking peoples'. ${ }^{106}$ During their outspoken opposition to Magna Charta day, the Boston Knights of St Columba also focused on the figure of Murray Butler. With the presidents of Michigan and Princeton universities, and the president emeritus of Minnesota university, all serving on the IMCDA's national committee, the concerns of the Boston Knights and the Anglophobes in Chicago regarding what role American educators were playing in the Magna Charta celebrations had some basis in reality. ${ }^{107}$

\section{The Impact of Hamilton and the IMCDA}

Hamilton's chances of achieving his aim of an Anglo-world Magna Charta day were both aided and diminished by his enthusiasm for a diverse range of methods to achieve international peace. Hamilton's principal publications were two short pamphlets advocating 'World' or 'Cosmo'

\footnotetext{
${ }^{104}$ New York Times, 21 March 1926; The Sulgrave Review, No. 3, Sulgrave Mss, Sulgrave Manor Trust Archive, [SMTA], Box 2.

${ }^{105}$ The Times, 24 February 1919.

${ }^{106}$ William B. Howland to Harry Brittain, 29 January 1912, Sulgrave Mss, SMTA, Box 1; Anne P. Baker, Pilgrims of the United States: A Centennial History (London: Profile Books, 2003), 152.

${ }^{107}$ New York Times, 8 September, 7 December 1921. Marion Burton, University of Michigan, John Grier Hibben, Princeton University, Cyrus Northrop, University of Minnesota.
} 
English, ${ }^{108}$ something he pushed hard alongside his campaign for the adoption of a standardised postage stamp dedicated to universal peace, and his exertions for the recognition of Magna Charta Day as an elective, Anglo-world celebration of the foundations of common liberties. If Magna Charta Day was aimed at the seven English-speaking nations, the World Peace Postage Association was aimed more widely still. ${ }^{109}$ Upholding the ancient liberties of Magna Charta brought this inveterate letter-writer into communication with representatives in the US and all of Britain's former colonies of settlement. He also wrote to prominent politicians, such as the British Labour Party's Arthur Henderson, about an International Memorial Day, when the plan was for every worker in the world to reflect for five minutes at noon on the $30^{\text {th }}$ May each year. ${ }^{110}$ In pursuance of a common language Hamilton communicated with Scandinavian and German scholars. He founded the International Peace Postage Stamp Association to unite the world in the name of peace, bringing him into regular touch with postmasters, peace-campaigners, and politicians from Buenos Aires to Spain, and France to China. He also communicated with others about an International Memorial Day, another feature of his cause of global peace and understanding. ${ }^{111}$ All these things he did without clerical help from his modest lodgings in St Paul, Minnesota, where he was secretary of several associations he himself founded. His letters also revealed the extent of some of his more half-baked and over-extended ideas. Winifred Coombe-Tennant, the Suffragette, spiritualist and magistrate, received a copy of another of his publications, Magna Charta of Peace for the World, with a question: 'Why not try and have International Mind Alcoves put in every school in every country on earth?'112

Hamilton's published output may have been small, but his correspondence was massive, costing him, he claimed, one-third of his salary as a clerk, sales manager for Finch, Vanslyck and

\footnotetext{
${ }^{108}$ World English: A Suggestion that we Simplify English as the International Language for the World (St Paul, Minn., 1922); World or Cosmo English: A Proposal to Simplify English as the International Auxiliary Language for the World (St Paul, Minn., 1928).

${ }^{109}$ Hamilton's correspondences around this issue are found in LOC, MMC 2565, World Peace Postage Association records, 1911-1937.

${ }^{110}$ Ibid., Hamilton to Henderson, 10 August 1921.

${ }^{111}$ World Peace Postage Association files, LOC MMC-2565, Hamilton, letter to Charles L. Bernheimer, 3 Sept 1929.

${ }^{112}$ Ibid., Hamilton to Coombes-Tennant, 26 April 1927. Also see Hamilton to Roger Alton Pfaff, Oregon, 20 May 1932.
} 
McConville Dry Goods Company, and, later, an English teacher. His views traversed the globe as he built on information provided by key individuals to develop webs of potential correspondents. Whilst he wrote to politicians from the interwar US presidents down, he also had regular correspondents, such as Sir James Barrett, English-Australian organiser of Hamilton's own Magna Charta Day Association. Academics were favoured targets for his letters. Writing in September 1922 to Louis M. Brandin, Professor of Philology at University College London, his letter revealed a common modus operandi. First, he asked Brandin for the names of suitable philologists 'outside the British Empire' and 'the names of any gentlemen of the British Empire also'. Secondly, he sought criticisms for his plans for 'World English'. Thirdly, he explained the meaning behind his plan: 'English is the language of the sea; of commerce and of freedom and democracy. ${ }^{113}$

In a letter to Eleanor Moore, honorary secretary of the Sisterhood of International Peace, Melbourne, Hamilton pressed the efficacy of World Memorial Day and Magna Charta Day, by being at pains to point out that they were not proposed as 'legal holidays'. ${ }^{114}$ Moore's response would have disappointed Hamilton, stating how unlikely it was another such day could be adopted (on his proposed date of 30 May) given it came so close to Easter and Anzac Day (25 April). She also questioned why fighting men, rather than those in other forms of work, should be specially remembered this way. For her days marking wars and battles were merely 'flag waving and national vainglory'. ${ }^{115}$

Hamilton was more successful with the media. Discussion of the international celebration of Magna Charta made news in many journals - those of different churches, Rhodes scholars, lawyers, social workers, and others who might wish to join the movement. ${ }^{116}$ The Boy Scouts, for example,

\footnotetext{
${ }^{113}$ James Woodburn Hamilton papers, 1911-1939, LOC, MMC-0688, Box 1, Letter to Professor Louis M. Brandin, 5 Sept 1922.

114 World Peace Postage Stamp Association files, Hamilton to Moore, 5 November 1921.

115 Ibid., Moore to Hamilton, 14 Sept ember 1921.

${ }^{116}$ The American Oxonian, vol. 13 (1926), 63; Year Book of the Disciples of Christ (1926), 14; Proceedings of the National Conference of Social Work, 51 (1924), 176.
} 
were told how American President Coolidge sent an approving, though political, letter to the association:

The purposes, if I correctly understand them, of the effort to establish an International Magna Charta Day Association are such as surely must appeal to all friends of constitutional government. From the day of Magna Charta, it has spread literally to all quarters of the world, and is recognized everywhere as the bulwark, on the one side, against the extreme weaknesses of conservatism, and on the other, against those of radicalism. ${ }^{117}$

Dedicated journals such as The English-Speaking Union naturally reported approvingly on the success of Hamilton's campaign. ${ }^{118}$ Since one angle of Magna Charta Day was to educate the English-speaking world, it is unsurprising that education journals wrote approvingly of the news that English members met at Runnymede and American members met simultaneously in Philadelphia. ${ }^{119}$ The Spectator thought it 'difficult to exaggerate' the 'significance of the entire English-speaking world fixing on an annual celebration of the day which witnessed the birth of their common free institutions in the 'meadowlands of Runnymede'. ${ }^{120}$ In Washington, in 1935, plans were taking shape to mark Constitution Day with a re-enactment of the constitutional convention and a pageant depicting the writing of the American constitution and the signing of the Magna Charta. It was suggested that 75 or more patriotic, civic, business, religious, military and fraternal societies, totalling 5000 people, would participate in a torchlight procession. ${ }^{121}$ When war broke out in 1939 , the press reportage became a little more muted, since the Americans were wary of both British and French propaganda. A local Wisconsin paper, once again drawing links between the IMCDA, the Pilgrims and the ESU, captured it well:

\footnotetext{
${ }^{117}$ Boy's Life: The Boy Scouts Magazine, June 1924, 36.

${ }^{118}$ English-Speaking Union, 5 (1924), 284.

${ }^{119}$ Intellect, Journal of the Society for the Advancement of Education, 24 (1926), p.38; see also Nova Scotia's Journal of Education, 6 (1926), 103.

${ }^{120}$ Spectator, 130 (1926), 751.

${ }^{121}$ Washington Post, 8 September 1935. Constitution Day was apparently instituted in 1918 by the Sons of the American Revolution. Atlanta Constitution, 5 September 1937.
} 
Just as the Germans count on Americans of German background to do their work here, so the British rely on Americans with British connections - and there are more of them. The English-Speaking Union has been very active, and the Pilgrim Society only less so. The International Magna Charta Day association is reviving interest in its plans to make June 15 a common celebration of the United States, Britain, Canada, Australia, and the other dominions to strengthen the ties that bind them together.

Behind this description was alertness to the prospect of propaganda. Even in trade, 'the always proBritish House of Morgan will soon again become fiscal agents for the British government as in 1914. That purely commercial connection is not without its propaganda influence., 122

By the early 1940s Hamilton was able to boast that major newspapers, like the New York Times, were carrying editorials on the Magna Carta Day on the 15 June, and that radio broadcasts by the BBC also spoke in favour of the movement. ${ }^{123}$ Indeed, by 1942, with America also embroiled in the war, Magna Charta was once again a beacon of unquestioned liberty, celebrated in churches and lauded as the symbol of a greater world that would emerge after the conflagration had ended. At a service in St John the Divine, New York, held on Magna Charta Day in America, 1942, 2000 congregants, including the British Minister in Washington, heard the current conflict described as 'the modern world-wide struggle for the principles of Magna Charta. ${ }^{124}$

War-time also saw Hamilton embark on his most audacious campaign: to press for the British to gift a copy of the Magna Carta to the United States. At the beginning of the war in Europe, safekeeping of Lincoln Cathedral's copy of the Magna Charta (one of only four surviving original copies) was entrusted to the Library of Congress in Washington DC to protect it from the expected German invasion of Britain. Alert to British sensibilities, President Franklin D. Roosevelt remarked

\footnotetext{
${ }^{122}$ Sheboyan Press (Wisconsin), 12 September 1939; also verbatim in other local titles, such as Kingsport Times (Tennessee), 27 September 1939.

${ }^{123}$ New York Times, 15 June 1944; Letter from J.W. Hamilton to Leopold Amery, 20 June 1944

${ }^{124}$ New York Times, 15 June 1942.
} 
to the Librarian of Congress, Archibald MacLeish, that his plan for taking care of the Magna Charta was 'excellent' but he anticipated one difficulty: 'there may be a good many cartoons and some ribald remarks in and out of the press about the surrender of the great British Magna Charta to the young stepchild that goes by the name of the United States' and advised him that

in your remarks you can make the happy suggestion that there could properly be criticism if the Magna Carta had been turned over to the executive branch of government, i.e., the King John of modern days; but that as the Library is the Library of Congress the precious document has been retained in the safe hands of the barons and the commoners. ${ }^{125}$

Deposited in the Library of Congress on 28 November 1939, the Magna Charta was later placed at Fort Knox, along with the Declaration of Independence and the US Constitution. Prior to its arrival in the US Hamilton had attempted to persuade the British government to give the Lincoln Magna Charta as a permanent gift in order to strengthen Anglo-American friendship. Writing to Leo Amery in June 1939 he told him that as a follow-up to the recent visit to the US (and Canada) by the King and Queen, the gift 'would cap' the 'splendid impression' they made on the American people, and 'would be an act never to be forgotten in this country'. ${ }^{126}$ As requested, Amery brought the idea to the idea of Prime Minister Neville Chamberlain. Although thinking it an 'interesting' idea and having looked into it, the Prime Minister dismissed it. Conscious that Britain was anxious for the US to end its wartime neutrality, he told Amery that 'such a gift would merely be represented in malevolent quarters as a clumsy bribe to gain American goodwill. ${ }^{127}$ Later in the war, and with Britain even more anxious about the lack of American military intervention in the war, Prime Minister Churchill again considered gifting the Lincoln copy to the US. The Dean of Lincoln Cathedral was much less impressed by the idea, reminding Hamilton that they were merely 'trustees'

\footnotetext{
${ }^{125}$ Franklin D. Roosevelt to Archibald MacLeish, 4 November 1939, LOC, http://memory.loc.gov/master/mss/mff/003/003002/0001.jpg

${ }^{126}$ Letter from J.W. Hamilton to Leopold Amery, 12 June 1939, Churchill Archives

${ }^{127}$ Letter from 10 Downing Street to Leopold Amery, 30 June 1939, TNA
} 
of the document. ${ }^{128}$ Pearl Harbor ended the discussion and in 1944 the copy was returned to the Library of Congress and placed under Marine guard until the end of the war.

After the war, celebrations of Magna Charta and the American Constitution continued, but now a new document was added to the vault of liberty, as the Georgia D.A.R. members were told: 'The United Nations' Charter, new and untried' was 'built upon the same principles and designed to further elevate and guarantee certain "inalienable rights" to all mankind. ${ }^{129}$ Addressing the $52^{\text {nd }}$ Continental Congress of D.A.R., Robert Kazmeyer exhorted: 'so let us add to the Constitution and the Magna Charta this last great international charter and have faith that it, too, will be unbelievably powerful in uplifting and bringing law, order and justice to mankind. ${ }^{130}$ Still another document was added to this list in 1949 when Eleanor Roosevelt described the Universal Declaration of Human Rights as 'the international Magna Carta for all men everywhere'. ${ }^{131}$

In England, the Magna Carta Society_-founded in 1921, and distinct from the IMCDA—was replaced in 1956 by the Magna Carta Trust, which promotes the Magna Charta and the memorial to it which the American Bar Association gifted to the people of Runnymede. ${ }^{132} 5000$ Britons and Americans gathered at Runnymede to see the unveiling of the Portland stone monument, some playing cricket and football while they heard 'British and American orators extol the Magna Charta as a symbol of the faith of Anglo-Saxons in the rule of law. ${ }^{, 133}$

The crossover in membership between the various Anglo-Saxon societies continues to the present day, with former Pilgrims chairman and founder of Ipsos Mori, Sir Robert Worcester, also

\footnotetext{
${ }^{128}$ Letter from Nugent Lincoln to Leopold Amery, 30 August 1939, Churchill Archives

129 Atlanta Constitution, 16 September 1945.

${ }^{130}$ Ibid.

${ }^{131}$ From the UNA-UK journal United Nations News, March/April 1949. The speech can be heard at http://www.americanrhetoric.com/speeches/eleanorrooseveltdeclarationhumanrights.htm [accessed 28 February 2012].

${ }^{132}$ http://www.magnacartatrust.org.uk/; The Times, 25 June 1956; New York Times, 29 July 1957.

133 New York Times, 29 July 1957.
} 
acting as the chair of the Magna Carta Trust. ${ }^{134}$ Historically, the support of such people for Magna Charta day matched a wider elite interest in British-American relations and demonstrates why the IMCDA should be regarded as part of a network of groups working to bring the two countries closer together in cultural and political terms. Magna Charta had become part of the efforts of these elite groups to enhance Anglo-Saxon hegemony and was a symbol of the myth of the English roots of fairness and the rule of law. These were ideas which the Pilgrims Society advocated, not least when they evoked the names of a 'great procession of Englishmen and men of English blood', including Alfred the Great, Oliver Cromwell, George Washington and Abraham Lincoln, and rhetorically asked his British and American counterparts to consider "what other peoples have pursued liberty longer $[\ldots]$ and with greater success? ${ }^{, 135}$

\section{Conclusion}

The IMCDA died out in the years after the Second World War. In some ways, its aims had been achieved in that the United Nations Charter extolled the values of the Magna Charta to a global audience. Hamilton would also have been delighted to see the emergence of a 'special relationship' between Britain and the United States; one that emerged during the Second World War in the shape of close military and political co-operation and was cemented in the early years of Cold War in unprecedented levels of collaboration in the intelligence and defence fields. The founder of the IMCDA was also well aware that it had, in many ways, been a 'one-man show' and sensed it would struggle to cease after him if a similarly energetic and committed figure did not emerge. Shortly before his own death, convalescing in a nursing home in North Carolina, Hamilton admitted to his old friend and supporter, Leo Amery, that he had 'broken' his health and 'impoverished myself in

\footnotetext{
${ }^{134}$ BBC News, 'Queen Becomes Patron of the Magna Carta Trust', 28 October 2011, http://www.bbc.co.uk/news/ukengland-surrey-15497490, [accessed 27 June 2012].

135 'Introductory Remarks at the Banquet of the Pilgrims of the United States', 5 March 1918, Brittain papers, BLPES, Box 7.
} 
furthering the work' of the association. ${ }^{136}$ But he acknowledged that to a large extent the aims of the ICMDA - to promote Anglo-American goodwill - had been achieved: 'at the end of a 40-year campaign, in which I have not spared myself, I feel that we are now within sight of the goal.' The IMCDA may have been only one element in the widening and strengthening of Anglo-world connections, but it was an important one. It was, in sum, a colourful piece in a mosaic of groups that forged closer Anglo-world bonds during this early twentieth century. The IMCDA was consciously internationalist in outlook but framed by debates about the nature of Americanism and over the duty of the 'White Race' to educate the nations of the world. In this respect, though internationalist and pacifist, groups like the IMCDA were also imperialist. English-speaking hegemony could not be achieved through Anglo-Saxonism - with its controversial and irrational emphasis on race and blood. Universal values and symbols, such as liberty and democracy, had wider appeal but achieved, consciously or subconsciously, the same ends.

For its part, the IMCDA captured wider concerns about the cultural expression of common origins in the Anglo-world. The express usage of churches and schools to spread the message of cultural connection implied aspects of social control. In the age of democracy, it was considered inherently important to inculcate the masses with elite values. For a time during the twentieth century Linebaugh tells us, 'the cultural development of Magna Carta led to its reification: it ceased to be an active constitutional force and became a symbol characterized by ambiguity, mystery, and nonsense [...] It became an idol of the ruling class. ${ }^{, 137}$ This was manifest in the links that existed between the IMCDA and groups like the Pilgrims. For Linebaugh this was part of a 'political rhetoric of English and American imperialism in the late nineteenth and early twentieth century [which] developed the

\footnotetext{
${ }^{136}$ Letter from J.W. Hamilton to Leopold Amery, 20 January, 1947, Churchill Archives Centres, Churchill College, Cambridge

${ }^{137}$ Linebaugh, Magna Carta Manifesto, 192.
} 
concept of Western civilization as a political and historical expression separate from the rest of the world. ${ }^{138}$ That this was so, does not diminish its importance.

Much of the success of the IMCDA was down to the extraordinary efforts of J.W. Hamilton, whose devotion to the cause of world peace and an alliance of the English-speaking peoples saw him achieve considerable influence and strong connections through a cottage-industry of letter-writing. Whilst groups like the IMCDA had also read history in an inimitable way, it was partly their deployment of the English King John and his Magna Charta that has determined how the Angloworld - and the British-American relationship - in the twentieth century has been both thought about and acted out. Today, however, the need for symbols to underscore the Anglo-American relationship is less apparent than it once was. Perhaps this is why Prime Minister David Cameron was unable to answer David Letterman's basic questions on Magna Charta during an interview that was broadcast across the globe. ${ }^{139}$ Hamilton would, of course, have been appalled.

\footnotetext{
${ }^{138}$ Linebaugh, Magna Carta Manifesto, 200.

139 e.g. Daily Telegraph, 27 September 2012.
} 